\title{
Mild-Base-Promoted Arylation of (Hetero)Arenes with Anilines
}

\author{
Diego M. Monzón,,${ }^{[a] \dagger}$ Tanausú Santos, ${ }^{[a] \dagger}$ F. Pinacho-Crisóstomo, ${ }^{[a]}$ Víctor S. Martín, ${ }^{[a]}$ and Romen \\ Carrillo*[a]b]
}

Dedication ((optional))

\begin{abstract}
Transition metal-free radical arylation of heteroarenes is achieved at room temperature by simply adding aqueous sodium carbonate to a solution of the corresponding heteroarene and arenediazonium salt, which can even be formed in situ. Such an easy, inexpensive and mild methodology has been optimized and applied to the expeditious modification of interesting molecular cores like naphthylimide or bisthienylcyclopentenes.
\end{abstract}

\section{Introduction}

Biaryl compounds are truly privileged structures: Plenty of molecules with applicability in fields ranging from materials science to biomedicine display a carbon-carbon bond between aromatic rings. Therefore, the development of selective and mild arylation reactions is a critical goal in chemistry. ${ }^{1}$ Traditional cross-coupling strategies based on transition metal catalysis have been very fruitful, and yet there is a growing demand of arylation reactions which do not require expensive or scarce metals. $^{2}$ In fact, there are stricter environmental laws, an increasing social awareness, and the issue of trace metal contamination. Indeed, it is well known that the level of heavy metals is limited by strict guidelines in pharmaceutically active compounds; ${ }^{3}$ less known is that metal traces may also be devastating for the performance and properties of organic materials and devices. ${ }^{4}$ Radical arylations have recently arisen as an optimal alternative to traditional coupling methods. ${ }^{5}$ Such kind of reaction must always start by the convenient generation of an aryl radical (Scheme 1a), which then undergoes an addition to an arene that does not need to be functionalized. Considering what has been said above, a mild and metal-free method to generate the aryl radical would be optimal. ${ }^{6}$ Herein we will take advantage of the long known diazo anhydrides (Scheme $1 b),{ }^{7}$ not only because they are easily synthesized from the corresponding diazonium salt with mild bases, but also because they are prone to decompose into aryl radicals. ${ }^{8}$

[a] Mr. D. M. Monzón, Mr. T. Santos, Dr. F. Pinacho-Crisóstomo, Prof. V. S. Martín, Dr. R. Carrillo

Departamento de Química Orgánica

Instituto Universitario de Bio-Orgánica "Antonio González" (IUBO), Universidad de La Laguna

Avda. Astrofísico Fco. Sánchez 2, Apdo. Correos 456, 38200 - La Laguna, S/C. de Tenerife, Spain

E-mail: rocarril@ull.es

[b] Dr. R. Carrillo

Instituto de Productos Naturales y Agrobiología

Consejo Superior de Investigaciones Científicas (IPNA-CSIC)

Avda. Astrofísico Fco. Sánchez 3, 38206 - La Laguna, S/C. de

Tenerife, Spain.

$\dagger \quad$ These authors contributed equally to this work

Supporting information for this article is given via a link at the end of the document.((Please delete this text if not appropriate))
Actually, Gomberg and Bachmann detected arylations back in 1924, when diazo anhydrides were solved in aromatic solvents. ${ }^{9}$ However, yields of the Gomberg-Bachmann reaction are usually very poor. ${ }^{10}$ There are, though, a few interesting precedents reporting reasonable yields, such as the recent work by de Frutos, Kappe and coworkers; ${ }^{11}$ or by Gokel and coworkers longer ago. ${ }^{12}$ Yet in both cases successful reactions are only achieved by irradiation or after the addition of a phase transfer catalyst and very large amounts of reagent. And in both cases pre-formed diazonium salts are employed.

a) Radical Arylation

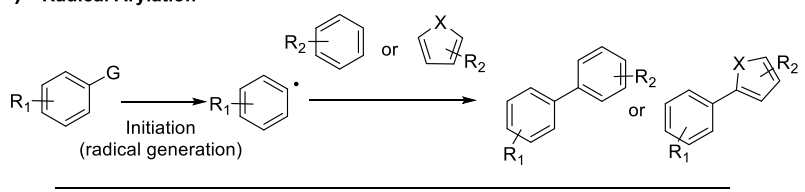

b) This work

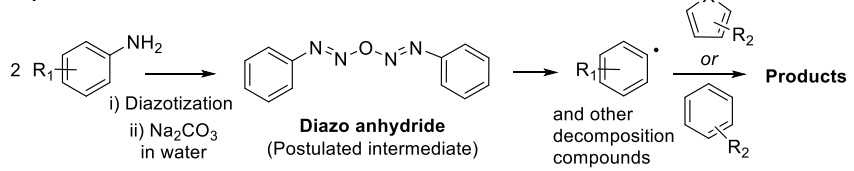

Scheme 1. (a) General scheme of a radical arylation. (b) Optimized Gomberg-Bachmann reaction.

Still, other arylations promoted by weak bases, ${ }^{13,14}$ made us think that it could be feasible to optimize the GombergBachmann arylation without the requirement of any other additive than a mild base. Herein, the arylation of (hetero)arenes with anilines promoted by weak bases has been explored and optimized. Heteroarenes are very important for two reasons: On one hand, they are usually more effective radical acceptors than substituted benzenes and with better regioselectivity, ${ }^{15}$ therefore higher yields are expected; on the other hand, heteroarene derivatives are common scaffolds in drugs and organic semiconductors, thus this methodology could be applied to the development of high added value compounds for the pharmaceutical or the organic electronics industries, without the concern of transition metal traces.

\section{Results and Discussion}

An initial attempt with 4-chlorobenzenediazonium tetrafluoroborate and furan in acetonitrile (Scheme 2), adding just 2 equivalents of sodium carbonate as a $1 \mathrm{M}$ aqueous solution, led only to traces of 2-(4-chlorophenyl)-furan (2a) after 1 hour. Instead, lactol 1 was isolated in a reasonable yield (67\%). Although 1 was not the expected product, this compound is a valuable intermediate since it could be easily dehydrated and rearomatized to the desired product under acidic conditions. ${ }^{16}$ Indeed, by simply working up the reaction with a slight excess of $\mathrm{HCl} 1 \mathrm{M}$, then $70 \%$ yield of the desired compound is obtained. 


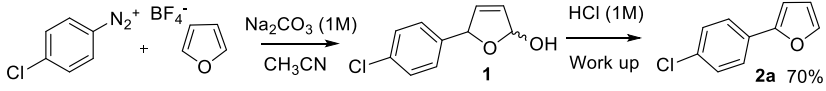

Scheme 2. Initial Experiment.

Several bases were tested to optimize this reaction, but all of them gave lower yields (Table 1, entries 2-8). Nor increasing or decreasing the amount of sodium carbonate drove to a better yield (entries 9 and 10). Worth to mention, no final product was isolated when no base but just water was added to the reaction mixture (entry 11).

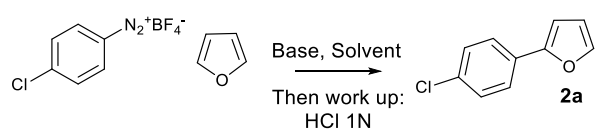

Table 1. Optimization of the coupling reaction between 4chlorobenzenediazonium tetrafluoroborate and furan. ${ }^{[a]}$

\begin{tabular}{|c|c|c|c|}
\hline Entry & Base $^{[b]}$ & Solvent & Yield $^{[c]}$ \\
\hline 1 & $\mathrm{Na}_{2} \mathrm{CO}_{3}$ & $\mathrm{CH}_{3} \mathrm{CN}$ & 70 \\
\hline 2 & $\mathrm{~K}_{2} \mathrm{CO}_{3}$ & $\mathrm{CH}_{3} \mathrm{CN}$ & 60 \\
\hline 3 & $\mathrm{Li}_{2} \mathrm{CO}_{3}$ & $\mathrm{CH}_{3} \mathrm{CN}$ & 59 \\
\hline 4 & $\mathrm{Cs}_{2} \mathrm{CO}_{3}$ & $\mathrm{CH}_{3} \mathrm{CN}$ & 57 \\
\hline $5^{[\mathrm{d}]}$ & $\mathrm{CaCO}_{3}$ & $\mathrm{CH}_{3} \mathrm{CN}$ & 13 \\
\hline 6 & $\mathrm{AcONa}$ & $\mathrm{CH}_{3} \mathrm{CN}$ & 10 \\
\hline 7 & $\mathrm{~K}_{3} \mathrm{PO}_{4}$ & $\mathrm{CH}_{3} \mathrm{CN}$ & 65 \\
\hline 8 & $\mathrm{NaOH}$ & $\mathrm{CH}_{3} \mathrm{CN}$ & 5 \\
\hline $9^{[e]}$ & $\mathrm{Na}_{2} \mathrm{CO}_{3}$ & $\mathrm{CH}_{3} \mathrm{CN}$ & 67 \\
\hline $10^{[\mathrm{f}]}$ & $\mathrm{Na}_{2} \mathrm{CO}_{3}$ & $\mathrm{CH}_{3} \mathrm{CN}$ & 59 \\
\hline 11 & - & $\mathrm{CH}_{3} \mathrm{CN}$ & - \\
\hline 12 & $\mathrm{Na}_{2} \mathrm{CO}_{3}$ & Acetone & 62 \\
\hline 13 & $\mathrm{Na}_{2} \mathrm{CO}_{3}$ & $\mathrm{MeOH}$ & 40 \\
\hline 14 & $\mathrm{Na}_{2} \mathrm{CO}_{3}$ & Water & 17 \\
\hline $15^{[\mathrm{g}]}$ & $\mathrm{Na}_{2} \mathrm{CO}_{3}$ & $\mathrm{CH}_{3} \mathrm{CN}$ & 72 \\
\hline $16^{[\mathrm{h}]}$ & $\mathrm{Na}_{2} \mathrm{CO}_{3}$ & $\mathrm{CH}_{3} \mathrm{CN}$ & 71 \\
\hline
\end{tabular}

[a] Reaction conditions: To 4-chlorobenzenediazonium tetrafluoroborate $(0.5$ $\mathrm{mmol})$ in the solvent $(5 \mathrm{ml})$ was added furan $(5 \mathrm{mmol})$ and finally $1 \mathrm{ml}$ of $1 \mathrm{M}$ aqueous solution of base $(1 \mathrm{mmol})$. After $1 \mathrm{~h}$ at room temperature, $2 \mathrm{ml}$ of $\mathrm{HCl}$ $1 \mathrm{M}$ was added and left stirring for another hour. b] $1 \mathrm{ml}$ of $1 \mathrm{M}$ aqueous solution except otherwise stated. [c] Isolated yield. [d] $1 \mathrm{ml}$ of saturated solution of $\mathrm{CaCO}_{3}$. [e] $0.75 \mathrm{mmol}$ of carbonate. [f] $2.5 \mathrm{mmol}$ of carbonate. [g] Under argon. [h] In the dark.

And regarding the organic solvent, acetonitrile proved to be the best one. Finally, the reaction under inert atmosphere increased slightly the yield (72\%, entry 15$)$, but no significant modification was observed when the reaction was set up in the dark (entry $16)$, thus precluding any relevant effect of the light in this reaction.
The one pot process, starting directly from the aniline is by far more appealing, and thus it was also explored and optimized (Table 2). tert-Butyl nitrite was chosen as diazotization agent, and left for 15 minutes before adding furan and sodium carbonate. However, the yield was poor (entry 1). It is well known that the addition of acid enhances the diazotization step. Therefore, a few acids were tested by adding them right after the tert-butyl nitrite. All of them increased the yield, particularly methanesulfonic acid (entry 5). Curiously, when more base was added, yield drops down (entry 6). Worth to mention, exhaustive control experiments were performed, and only a very low yield was obtained when no base was added. ${ }^{17}$

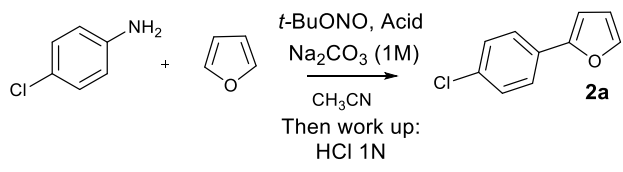

Table 2. Optimization of the one-pot coupling reaction between 4-chloroaniline and furan. ${ }^{[a]}$

\begin{tabular}{ccc}
\hline Entry & Base & Yield $^{[\mathrm{b}]}$ \\
\hline 1 & - & 30 \\
2 & $\mathrm{p}-\mathrm{TsOH}$ & 45 \\
3 & $\mathrm{AcOH}$ & 10 \\
4 & $\mathrm{BF}_{3} \cdot \mathrm{Et}_{2} \mathrm{O}$ & 67 \\
5 & $\mathrm{CH}_{3} \mathrm{SO}_{3} \mathrm{H}$ & 70 \\
$6^{[\mathrm{c}]}$ & $\mathrm{CH}_{3} \mathrm{SO}_{3} \mathrm{H}$ & 42 \\
\hline
\end{tabular}

[a] Reaction conditions: To 4-chloroaniline $(0.5 \mathrm{mmol})$ in acetonitrile $(5 \mathrm{ml})$ under argon, were added $t$-BuONO $(0.75 \mathrm{mmol})$ and the acid $(0.6 \mathrm{mmol})$. The reaction mixture was left 15 minutes stirring and then, furan $(5 \mathrm{mmol})$ and finally $1 \mathrm{ml}$ of $1 \mathrm{M}$ aqueous solution of $\mathrm{Na}_{2} \mathrm{CO}_{3}$ (1mmol) were added. The reaction was left stirring $1 \mathrm{~h}$ at room temperature, and then $2 \mathrm{ml}$ of $\mathrm{HCl} 1 \mathrm{M}$ was added and left stirring for another hour. [b] Isolated yield. [c] $1.6 \mathrm{mmol}$ of $\mathrm{Na}_{2} \mathrm{CO}_{3}$ were added.

Once the conditions of both methods were optimized, the scope of the reaction was explored (Tables 3 and 4 ). The process starting from the diazonium salt (Method A) and the one pot methodology from the aniline (Method B) are compared throughout Tables 3 and 4 . It is clearly seen that acceptor substituted anilines (or diazonium salts) give higher yields. Also, as a general trend, furan and pyrrole-Boc lead to better results. Despite method A gives better yields in almost all cases, method $B$ has the advantage of avoiding pre-formation and manipulation of diazonium salts, which can be convenient in sensitive and/or expensive substrates.

In Table 3, several different functional groups were tested with furan and reaction conditions probed to be compatible with a good range of moieties, such as azides (2l), alkynes $(\mathbf{2 m})$, esters (2f), halogens (2a-c), ketones (2n), trifluoromethyl (2j), etc. Worth to mention, the substitution pattern slightly affects the reaction: para, meta and ortho-nitroaniline $(\mathbf{2 d}, \mathbf{2 h}, \mathbf{2 i}$ respectively) led to similar outcomes, being the meta substitution the highest in yield. However, 3,5-di-tert-butyl aniline led to very poor yields (2k). Larger scale did not affect substantially the outcome of the reaction $(\mathbf{2 a}, \mathbf{2 e})$. Additionally, respectable yields of arylation (20-2s) were also obtained with thiophene and pyrrole protected as Boc. And regarding the last one, it is worth mentioning that the acidic work up led to no deprotection of tertbutyl carbamate. 
Table 3. Scope of the reaction.

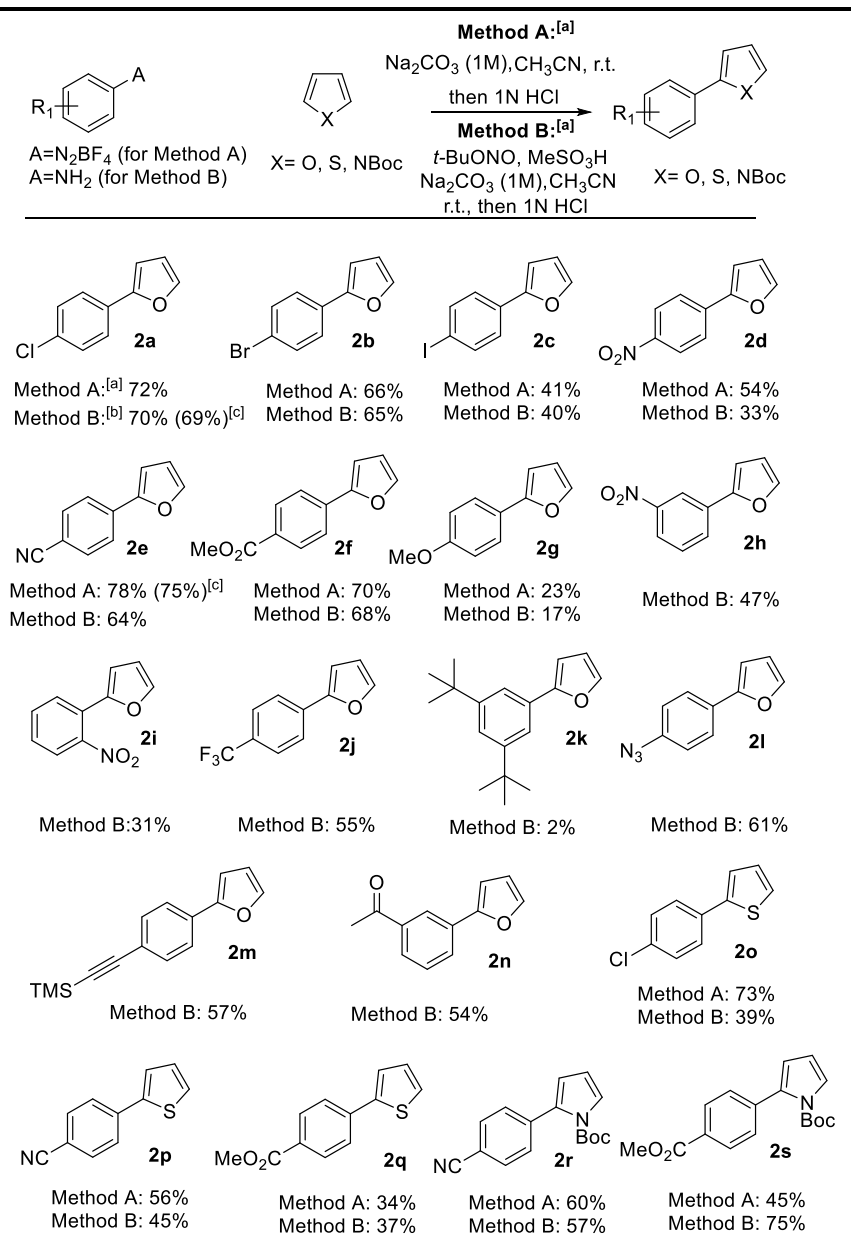

[a] For detailed conditions of method A or [b] method B, see the Experimental Section. [c] $2 \mathrm{mmol}$ scale

The scope of the present methodology was also tested with the arylation of benzene, as expected lower yields were found (Table 4). As expected lower yields were found than those compared to furan, thiophene and pyrrole.

It is very interesting to compare the present methodology with the previously described by Gokel, ${ }^{12}$ via phase transfer catalysis (Table 5). Regarding furan and thiophene, results obtained with our methodology are better than those reported by Gokel. It is worth to mention that Gokel must employ a huge excess of furan or thiophene (above 100 equivalents) and more drastic conditions. Actually, Heinrich reproduced Gokel conditions, but employing 10 equivalents of furan, ${ }^{14 c}$ and the yields were much lower, and considerably worse than ours. On the other hand, arylations of benzene or its derivatives with anilines are usually better obtained following Gokel's procedure, which reinforces the assumption that our procedures is specially indicated for the arylation of heteroarenes.
Method A: ${ }^{[a]}$

$\mathrm{Na}_{2} \mathrm{CO}_{3}(1 \mathrm{M}), \mathrm{CH}_{3} \mathrm{CN}$, r.t.

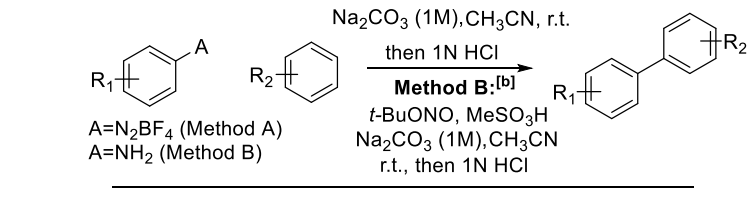<smiles>Clc1ccc(-c2ccccc2)cc1</smiles><smiles>CC(=O)c1ccc(-c2ccccc2)cc1</smiles>
$\begin{array}{llll}\text { Method A: } 37 \% & \text { Method A: } 41 \% & \text { Method A: } 39 \% & \text { Method B: } 13 \% \\ \text { Method B: } 24 \% & \text { Method B: } 24 \% & \text { Method B: } 27 \% & \end{array}$<smiles>Brc1ccc(-c2ccccc2)cc1</smiles><smiles>Cc1ccc(-c2ccccc2)cc1</smiles><smiles>COc1ccc(-c2ccccc2)cc1</smiles><smiles>O=[N+]([O-])c1ccccc1-c1ccccc1</smiles>

Method B: $13 \%$<smiles>Cc1ccc(C)c(-c2ccc(Cl)cc2)c1</smiles>

Method B: $20 \%$

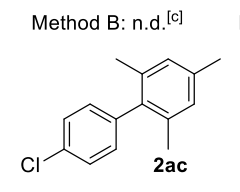

Method B: $6 \%$

[a] For detailed conditions of method A or method B, see the Experimental Section. [c] n.d.=not detected

Table 5. Comparing our methodology with Gokel's (ref. 12)

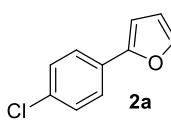

This work: ${ }^{[a]} 72 \%$ Gokel: $75 \%$

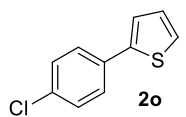

This work: ${ }^{[a]} 73 \%$ Gokel: $62 \%$

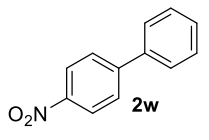

This work: ${ }^{[b]} 13 \%$ Gokel: $85 \%$
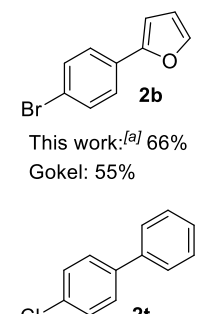

This work: ${ }^{[a]} 37 \%$ Gokel: $80 \%$
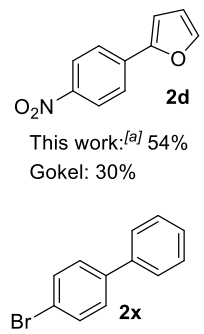

This work: ${ }^{[b]} 13 \%$ Gokel: $81 \%$ [a] method A [b] method B, see the Experimental Section.

As a further proof of the synthetic potential of this methodology, the arylation of a few interesting heteroarene molecular cores was tested (Scheme 3). For instance, menadione and its derivatives have been applied from anticancer treatments ${ }^{18}$ to green chemistry. ${ }^{19}$ As it is seen in Scheme 3a, menadione was derivatized in one step by method $B$ in good yield.

Table 4. Arylation of benzene and some derivatives. 
a)<smiles>CC1=CC(=O)c2ccccc2C1=O</smiles><smiles>COc1ccc(N)cc1</smiles>

b)<smiles>[B]OCCN1C(=O)c2cccc3c(N)ccc(c23)C1=O</smiles>

c)

d)

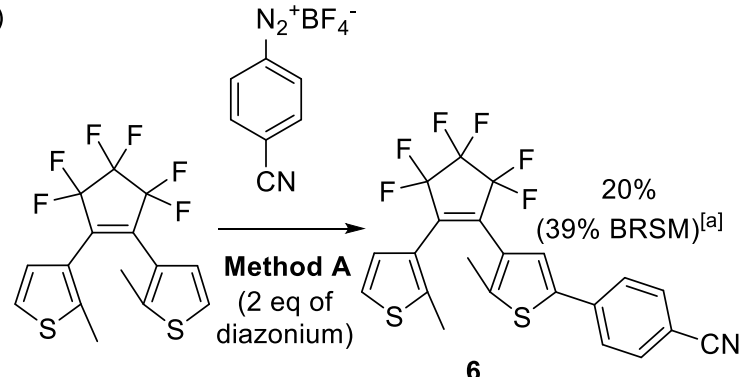

Scheme 3. Miscellaneous arylations. [a] BRSM=Based on Recovered Starting Material

Naphthylimides are a recurrent scaffold in fluorescent sensors and organic semiconductors. Herein we coupled in just one step the 4-amino-N-butyl-1,8-naphthalimide with furan (Scheme 3b), yielding the fluorescent compound $\mathbf{4}$ in a considerable yield. More interestingly, a similar reaction but using 2thiopheneacetonitrile instead of furan, also worked well (Scheme 3c). Compounds like 5 are really interesting, because they are just one reaction away from efficient non-fullerene acceptors for organic solar cells. ${ }^{20}$ Even when $41 \%$ yield in the synthesis of 5 may seem mediocre, it is much better than the reported 2-step procedure employing tin and palladium. ${ }^{21}$ Finally, diarylethenes are also a very attractive molecular core, due to their potential applications in photo-switching materials. ${ }^{22}$ In Scheme $3 d$, it is shown a preliminary result of the selective monoarylation of dithienylethene in a similar yield to that reported previously by Itami and coworkers using palladium chemistry. ${ }^{23}$ Curiously, this reaction always leave unreacted starting material, even if an excess of diazonium salt is employed. This result remains unchanged no matter if the reaction is set up in the dark or under UV irradiation. Further studies about such an intriguing behavior are under progress in our lab.

To shed some light on a plausible mechanism, some experiments were performed. Firstly, when the reaction between 4-chlorobenzenediazonium tetrafluoroborate and furan was set up under the method $A$ conditions but at higher temperature $\left(70^{\circ} \mathrm{C}\right)$, the yield was lower $(30 \%)$, which seems to discard the thermal initiation of the reaction. Additionally, the aryl radical was trapped with TEMPO and the adduct was isolated in $50 \%$ yield. Moreover, the formation of lactol 1 (Scheme 2), must imply that the radical addition to furan, is followed by a SET step, losing one electron and leaving a cation which is attacked by water. Considering these evidences and some precedents in the literature, ${ }^{11,13 a}$ a tentative mechanism is suggested (Scheme 4).

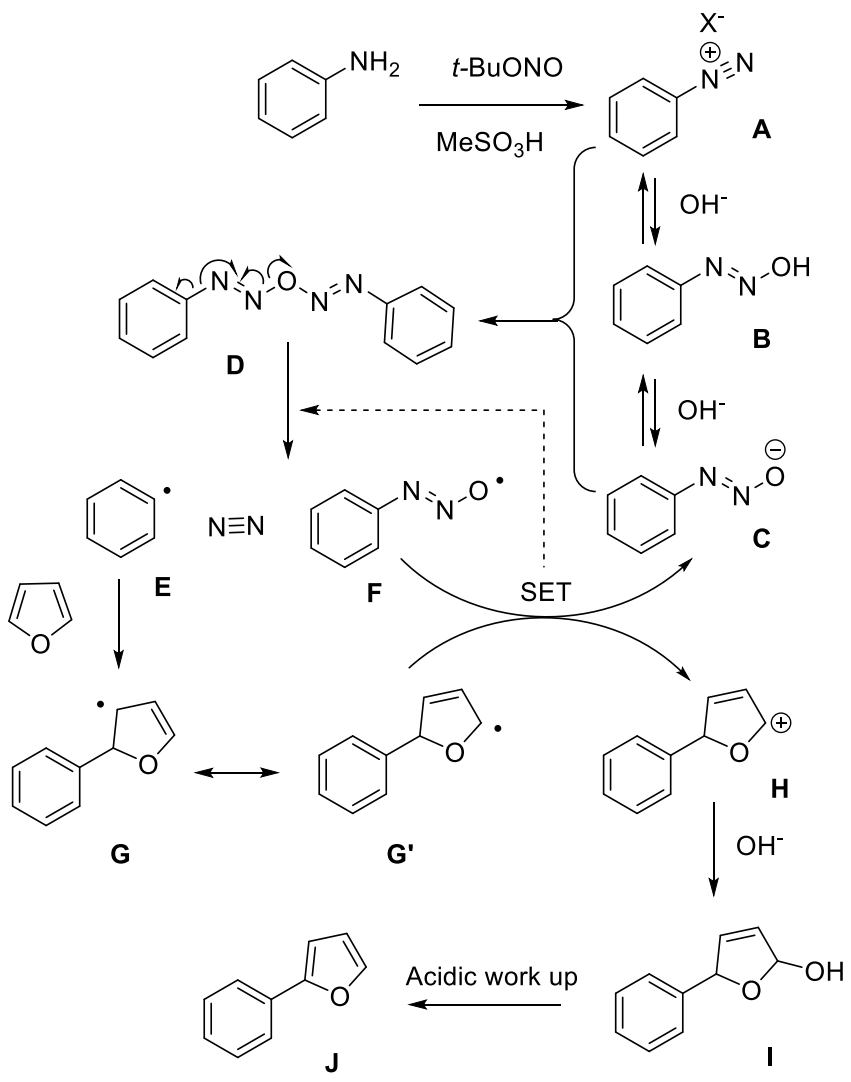

Scheme 4. Suggested mechanism

In the one pot methodology, the first step is the diazotization. Once the diazonium salt $(\mathbf{A})$ is formed, the mild basic aqueous environment favors the formation of the corresponding diazo anhydride (D), ${ }^{9 b}$ which is prone to decompose homolytically into aryl radical $(\mathbf{E})$, nitrogen and diazenyloxyl radical $(\mathbf{F})$. The aryl radical undergoes an addition to the heteroarene, giving radical 
$\mathbf{G} / \mathbf{G}^{\prime}$, which transfers one electron to the diazenyloxyl radical $(\mathbf{F})$. This SET process generates cation $\mathbf{H}$ and diazotate $\mathbf{C}$, which regenerates the diazo anhydride by addition to the diazonium salt. Another plausible pathway could be an electron transfer from radical G' directly to D (dashed arrow), which is a reasonably stable compound and therefore it is likely to be present in higher concentration in the reaction mixture than short-lived radical $\mathbf{F}$. In any case, cation $\mathbf{H}$ is attacked by one hydroxyl anion giving lactol I. Finally, by acidic dehydration during the work up, the final product is obtained.

\section{Conclusions}

In conclusion, a radical arylation of heteroarenes with anilines has been developed. Such a transition-metal free method is induced by aqueous sodium carbonate at room temperature. In such a way, Gomberg-Bachmann arylation has been optimized and updated, with no irradiation, phase-transfer catalyst or very large amounts of reagents required. Additionally, arylation of interesting molecular cores such as naphthylimide or bisthienylcyclopentenes has been achieved. Therefore, this mild, inexpensive and operationally simple method might well become part of the synthetic toolbox for material sciences and organic electronics.

\section{Experimental Section}

\section{Materials and Methods}

${ }^{1} \mathrm{H}$ NMR spectra were recorded at $600 \mathrm{MHz}, 500 \mathrm{MHz}$ and $400 \mathrm{MHz}$; and ${ }^{13} \mathrm{C}$ NMR spectra were recorded at $150 \mathrm{MHz} .125 \mathrm{MHz}$ and $100 \mathrm{MHz}$. Chemical shifts were reported in units (ppm) by assigning TMS resonance in the ${ }^{1} \mathrm{H}$ NMR spectrum as $0.00 \mathrm{ppm}$ (chloroform, $7.26 \mathrm{ppm}$ ). Data were reported as follows: chemical shift, multiplicity $(s=$ singlet, $d=$ doublet, $\mathrm{dd}=$ double doublet, $\mathrm{m}=$ multiplet and $\mathrm{br}=$ broad), coupling constant ( $\mathrm{J}$ values) in $\mathrm{Hz}$ and integration. Chemical shifts for ${ }^{13} \mathrm{C}$ NMR spectra were recorded in ppm from tetramethylsilane using the central peak of $\mathrm{CDCl}_{3}(77.00 \mathrm{ppm})$ as the internal standard. Accurate mass (HRMS) were determined by electrospray ionization (ESI-TOF) or electronic impact (El-TOF). Flash column chromatography was performed using silica gel, $60 \AA$ and $0.2-0.5 \mathrm{~mm}$ with the indicated solvent system according to standard techniques. Compounds were visualized on TLC plates by use of UV light, or vanillin with acetic and sulfuric acid in ethanol with heating. Anilines were purchased from commercial suppliers and used without further purification. All the solvents were treated according to general methods. Anhydrous magnesium sulfate was used for drying solutions.

\section{General Procedures}

\section{Synthesis of diazonium tetrafluoroborate salts.}

The corresponding aniline $(10 \mathrm{mmol})$ was dissolved in a mixture of $4 \mathrm{~mL}$ of distilled water and $3.4 \mathrm{~mL}$ of $50 \%$ hydrofluoroboric acid. After cooling the reaction mixture to $0^{\circ} \mathrm{C}$, sodium nitrite $(0.69 \mathrm{~g})$ dissolved in $1.5 \mathrm{~mL}$ of water, was added dropwise. The resulting mixture was stirred for $1 \mathrm{~h}$ and the precipitate was collected by filtration, washed with water and redissolved in minimum amount of acetone. Diethyl ether was added until precipitation of the corresponding diazonium tetrafluoroborate, which is filtered, washed several times with diethyl ether and dried under vacuum.

\section{Synthesis of $\mathrm{N}$-(tert-butoxycarbonyl)-pyrrole.}

Based on a literature procedure, ${ }^{24} \operatorname{DMAP}(0.12 \mathrm{~g}, 1 \mathrm{mmol})$ and di-t-butyl dicarbonate $(2.62 \mathrm{~g}, 12 \mathrm{mmol})$ were added to a solution of pyrrole $(0.69$ $\mathrm{mL}, 10 \mathrm{mmol})$ in acetonitrile $(10 \mathrm{~mL})$ and the solution was stirred at room temperature for 24 hours. The reaction mixture was diluted with $\mathrm{Et}_{2} \mathrm{O}$ and washed with $\mathrm{NaHCO}_{3}$ and then brine. The organic layer was then dried over $\mathrm{MgSO}_{4}$, filtered, and concentrated under reduced pressure. The crude product was purified by flash column chromatography Hex/AcOEt $(99: 1)$, yielding the title compound $(1.44 \mathrm{~g}, 86 \%)$ as a colorless oil.

\section{Synthesis of 4-amino-N-butyl-1,8-naphthalimide.}

Following a reported procedure, ${ }^{25}$ a mixture of 4-amino-1,8-naphthalic anhydride (400 mg, $1.88 \mathrm{mmol}$ ) and 1-butanamine (411.7 mg, 3.01 $\mathrm{mmol})$ in ethanol $(25 \mathrm{~mL})$ in a single necked flask and was heated to reflux under argon for 4 hours. After cooling to room temperature, the solvent was removed under reduced pressure and purification by flash column chromatography Hex/AcOEt (70:30), giving an orange solid (438 $\mathrm{mg}, 87 \%$ yield).

\section{Synthesis of 4-azidoaniline.}

Following a reported procedure, ${ }^{26}$ 4-bromoaniline $(555 \mathrm{mg}, 3.22 \mathrm{mmol}$, 1.0 equiv) was taken in a mixture of $\mathrm{EtOH}-\mathrm{H}_{2} \mathrm{O}(7: 3,10 \mathrm{~mL})$ and sodium ascorbate (27.5 mg, $0.16 \mathrm{mmol}, 0.05$ equiv), Cul (63.3 mg, $0.32 \mathrm{mmol}$, 0.1 equiv), N,N'-dimethylethylenediamine ( $52 \mu \mathrm{L}, 0.48 \mathrm{mmol}, 0.15$ equiv) were added and stirred for $10 \mathrm{~min}$. Sodium azide $(350 \mathrm{mg}, 6.44 \mathrm{mmol}$, 2.0 equiv) was added to the reaction mixture and allowed to stir for $3 \mathrm{~h}$ at reflux under argon atmosphere. After complete consumption according to TLC analysis, the reaction was cooled, concentrated under vacuum and the crude product was purified by flash chromatography using hexaneethyl acetate (95:5) mixture to give the desired azide (397.4 mg, 92\%) as a brown solid.

\section{Synthesis of 4-((trimethylsilyl)ethynyl)aniline.}

Following a reported procedure ${ }^{27}$ 4-lodoaniline $(547 \mathrm{mg}, 2.5 \mathrm{mmol}, 1.00$ eq.), copper(I) iodide (10 mg, $0.05 \mathrm{mmol}, 2.0 \mathrm{~mol} \%)$, bis(triphenylphosphine)palladium(II) chloride $(70 \mathrm{mg}, 0.10 \mathrm{mmol}, 4.0$ mol\%) were added to dry NEt3 $(4 \mathrm{~mL}, 0.6 \mathrm{M})$. The mixture was stirred for $5 \mathrm{~min}$. Trimethylsilylacetylene ( $319 \mathrm{mg}, 3.25 \mathrm{mmol}, 1.30 \mathrm{eq}$.) was added under argon to this mixture and the mixture was stirred overnight at room temperature. $\mathrm{CH}_{2} \mathrm{Cl}_{2}(10 \mathrm{~mL})$ was added, the organic layer was washed with water $(10 \mathrm{~mL})$ and saturated aqueous ammonium chloride solution $(10 \mathrm{~mL})$ and dried over sodium sulfate. The solvent was evaporated under reduced pressure. Purification by column chromatography (hexane/ $\mathrm{CH}_{2} \mathrm{Cl}_{2}, 7: 3$ ) gave 4-((trimethylsilyl)ethynyl)aniline (341 mg, 1.80 $\mathrm{mmol})$ as an orange solid in $72 \%$ yield.

\section{Synthesis of 3,3'-(Perfluorocyclopent-1-ene-1,2-diyl)bis(2- methylthiophene).}

2-Methylthiophene was brominated with $\mathrm{N}$-Bromosuccinimide in acetic acid following a previously reported procedure, ${ }^{28}$ yielding the 2 , 4dibromo-5-methylthiophene as an oil (84\%). Then, it was subsequently lithiated selectively at position 2 , and reacted with water: A Schlenk tube 
equipped with a magnetic stirring bar and capped with a rubber septum was charged with 2, 4-dibromo-5-methylthiophene $(4.0 \mathrm{~g}, 15.6 \mathrm{mmol}, 1$ equiv.) followed by the addition of dry THF $(80 \mathrm{~mL})$. The solution was cooled to $-78^{\circ} \mathrm{C}$. At that temperature, a hexane solution of nBuLi $(1.6 \mathrm{~m}$, $9.8 \mathrm{~mL}, 17.2 \mathrm{mmol}, 1.1$ equiv.) was added dropwise with stirring. After 1 $\mathrm{h}$ at low temperature, the reaction was quenched by carefully adding water, followed by an extraction with $\mathrm{Et}_{2} \mathrm{O}$. The organics were combined, dried with anhydrous magnesium sulfate and filtered, and the solvents were removed under reduced pressure. The crude material was subjected to silica gel column chromatography using hexane as the eluent, to obtain 3-bromo-2-methylthiophene (which is also commercially available) as a colorless solid in $62 \%$ yield.

A flame-dried round bottom flask equipped with a magnetic stirring bar was charged with 3-bromo-2-methylthiophene $(1 \mathrm{~g}, 5.6 \mathrm{mmol}, 2.2$ equiv.) under a flux of nitrogen before dry THF $(20 \mathrm{~mL})$ was added. The solution was cooled to $-78{ }^{\circ} \mathrm{C}$ before a hexane solution of nBuLi $(1.6 \mathrm{M}, 3.5 \mathrm{~mL}$, $5.6 \mathrm{mmol}, 2.2$ equiv.) was added dropwise with stirring. Stirring was maintained over $1 \mathrm{~h}$ at low temperature. Perfluorocyclopentene is a low boiling temperature liquid, so it was transferred by tubing from the bottle where it is sold, to a Schlenk tube at $-78^{\circ} \mathrm{C}$ under argon, and kept in the freezer at $-20^{\circ} \mathrm{C}$. A portion from such a flask was quickly added $(340 \mu \mathrm{L}$, $2.6 \mathrm{mmol}, 1.0$ equiv.), and the mixture was allowed to slowly warm to room temperature. The reaction was quenched by addition of water. The biphasic system was extracted by adding $\mathrm{Et}_{2} \mathrm{O}$. The organics were washed several times with water, dried with anhydrous magnesium sulfate, filtered, and the solvents were evaporated under reduced pressure. The crude product was purified by a silica column chromatography using hexane as eluent, to afford a colorless solid (642mg, 67\% yield).

${ }^{1} \mathrm{H}$ NMR $\left(600 \mathrm{MHz}, \mathrm{CDCl}_{3}, 298 \mathrm{~K}\right): \delta \mathrm{ppm} 7.16(\mathrm{~d}, \mathrm{~J}=5.6 \mathrm{~Hz}, 2 \mathrm{H}), 7.06$ (d, J = 4.9 Hz, 2H), $1.88(\mathrm{~s}, 6 \mathrm{H}) ;{ }^{13} \mathrm{C} \mathrm{NMR}\left(150 \mathrm{MHz}, \mathrm{CDCl}_{3}, 298 \mathrm{~K}\right): \delta$ ppm 141.7, 136.2, 127.1, 124.9, 123.5, 116.2, 111.1, 14.0; HRMS (ESInegative): $\mathrm{m} / \mathrm{z}$ : calc for $\mathrm{C}_{16} \mathrm{H}_{22} \mathrm{~N}_{2} \mathrm{ONa}\left[\mathrm{M}-\mathrm{H}^{+}\right]$: 367.0050 , found: 367.0045 ; Column Chromatography: Hexane.

\section{General procedure for coupling from the diazonium salt (Method A).}

A $25 \mathrm{~mL}$ round bottom flask with a teflon-coated stirrer bar was charged with the corresponding arenediazonium tetrafluoroborate $(0.5 \mathrm{mmol})$. Then, $5 \mathrm{ml}$ of acetonitrile was added by syringe under an atmosphere of dry argon, followed by the addition of the corresponding arene $(5 \mathrm{mmol})$. Finally, $1 \mathrm{ml}$ of a $1 \mathrm{M}$ aqueous solution of sodium carbonate was added. The reaction mixture turns light orange and a fine bubbling starts thereafter. The reaction mixture was stirred at ambient temperature for 1 h. Then the reaction was worked up with $2 \mathrm{ml}$ of $1 \mathrm{~N}$ solution of $\mathrm{HCl}$ and left stirring for 1 hour. The reaction mixture was extracted three times with ethyl acetate $(10 \mathrm{ml})$. The organic layers were combined and dried with magnesium sulphate and filtered. The crude was adsorbed in silica gel, and purified by flash chromatography $\left(\mathrm{SiO}_{2}\right.$, hexane/ethyl acetate), yielding the corresponding (hetero)biaryl.

\section{General procedure for the one-pot coupling from the aniline (Method B).}

A $25 \mathrm{~mL}$ round bottom flask with a teflon-coated stirrer bar was charged with the corresponding aniline $(0.5 \mathrm{mmol})$. Then, $5 \mathrm{ml}$ of acetonitrile was added by syringe under an atmosphere of dry argon, followed by the addition of tert-butyl nitrite $(90 \%, 0.75 \mathrm{mmol})$ and methanesulfonic acid $(0.04 \mathrm{ml}, 0.6 \mathrm{mmol})$. The reaction mixture was left stirring for 15 minutes, and then the corresponding arene $(5 \mathrm{mmol})$ was added. Finally, $1 \mathrm{ml}$ of a $1 \mathrm{M}$ aqueous solution of sodium carbonate was added. The reaction mixture turns light orange and a fine bubbling starts thereafter. The reaction mixture was stirred at ambient temperature for $1 \mathrm{~h}$. Then the reaction was worked up with $2 \mathrm{ml}$ of $1 \mathrm{~N}$ solution of $\mathrm{HCl}$ and left stirring for 1 hour. The reaction mixture was extracted three times with ethyl acetate $(10 \mathrm{ml})$. The organic layers were combined and dried with magnesium sulphate and filtered. The crude was adsorbed in silica gel, and purified by flash chromatography $\left(\mathrm{SiO}_{2}\right.$, hexane/ethyl acetate), yielding the corresponding (hetero)biaryl.

\section{Characterization of Compounds.}

All compounds were purified by flash chromatography on $\mathrm{SiO}_{2}$. All compounds are amorphous solids, except from $\mathbf{2 i}, \mathbf{2 n}, \mathbf{2 r}$ and $\mathbf{2 2}$, which are oils.

2-(4-chlorophenyl)-furan (2a). ${ }^{1} \mathrm{H} \mathrm{NMR}\left(600 \mathrm{MHz}, \mathrm{CDCl}_{3}, 298 \mathrm{~K}\right)$ : $\delta \mathrm{ppm}$ $7.60(\mathrm{~d}, \mathrm{~J}=8.6 \mathrm{~Hz}, 2 \mathrm{H}), 7.48(\mathrm{br}, 1 \mathrm{H}), 7.36(\mathrm{~d}, \mathrm{~J}=8.6 \mathrm{~Hz}, 2 \mathrm{H}), 6.64(\mathrm{~d}, \mathrm{~J}$ $=3.3 \mathrm{~Hz}, 1 \mathrm{H}), 6.48(\mathrm{dd}, \mathrm{J}=1.7,3.2 \mathrm{~Hz}, 1 \mathrm{H}) ;{ }^{13} \mathrm{C} \mathrm{NMR}\left(150 \mathrm{MHz}, \mathrm{CDCl}_{3}\right.$, $298 \mathrm{~K})$ : $\delta$ ppm 152.9, 142.3, 132.9, 129.3, 128.8, 125.0, 111.7, 105.4 HRMS (El): $\mathrm{m} / \mathrm{z}$ : calc for $\mathrm{C}_{10} \mathrm{H}_{7} \mathrm{O}^{35} \mathrm{Cl}[\mathrm{M}+]$ : 178.0185 , found: $178.0185 /$ calc for $\mathrm{C}_{10} \mathrm{H}_{7} \mathrm{O}^{37} \mathrm{Cl}\left[\mathrm{M}^{+}\right]$: 180.0156, found: 180.0155; Column Chromatography: 98:2 (Hex-AcOEt)

2-(4-bromophenyl)-furan (2b). ${ }^{1} \mathrm{H} ~ \mathrm{NMR}\left(600 \mathrm{MHz}, \mathrm{CDCl}_{3}, 298 \mathrm{~K}\right)$ : $\delta \mathrm{ppm}$ $7.54(\mathrm{~d}, \mathrm{~J}=8.7 \mathrm{~Hz}, 2 \mathrm{H}), 7.50(\mathrm{~d}, \mathrm{~J}=8.7 \mathrm{~Hz}, 2 \mathrm{H}), 7.47(\mathrm{~d}, \mathrm{~J}=1.0 \mathrm{~Hz}, 1 \mathrm{H})$, $6.65(\mathrm{~d}, \mathrm{~J}=3.3 \mathrm{~Hz}, 1 \mathrm{H}), 6.48(\mathrm{dd}, \mathrm{J}=1.8,3.3 \mathrm{~Hz}, 1 \mathrm{H}) ;{ }^{13} \mathrm{C}$ NMR $(150$ $\left.\mathrm{MHz}, \mathrm{CDCl}_{3}, 298 \mathrm{~K}\right)$ : $\delta \mathrm{ppm} 152.9,142.3,131.8,129.8,125.3,121.0$, 111.8, 105.5; HRMS (EI): $\mathrm{m} / \mathrm{z}$ : calc for $\mathrm{C}_{10} \mathrm{H}_{7} \mathrm{O}^{81} \mathrm{Br}\left[\mathrm{M}^{+}\right]$: 223.9660 , found 223.9666 / calc for $\mathrm{C}_{10} \mathrm{H}_{7} \mathrm{O}^{79} \mathrm{Br}\left[\mathrm{M}^{+}\right]$: 221.9680, found: 221.9684; Column Chromatography: 95:5 (Hex-AcOEt)

2-(4-iodophenyl)-furan (2c). ${ }^{1} \mathrm{H} \mathrm{NMR}\left(600 \mathrm{MHz}, \mathrm{CDCl}_{3}, 298 \mathrm{~K}\right)$ : $\delta \mathrm{ppm}$ $7.71(\mathrm{~d}, \mathrm{~J}=8.4 \mathrm{~Hz}, 2 \mathrm{H}), 7.47(\mathrm{~d}, \mathrm{~J}=1.3 \mathrm{~Hz}, 1 \mathrm{H}), 7.41(\mathrm{~d}, \mathrm{~J}=8.4 \mathrm{~Hz}, 2 \mathrm{H})$ $6.66(\mathrm{~d}, \mathrm{~J}=3.3 \mathrm{~Hz}, 1 \mathrm{H}), 6.48(\mathrm{dd}, \mathrm{J}=1.7,3.2 \mathrm{~Hz}, 1 \mathrm{H}) ;{ }^{13} \mathrm{C}$ NMR $(150$ $\left.\mathrm{MHz}, \mathrm{CDCl}_{3}, 298 \mathrm{~K}\right)$ : $\delta$ ppm 153.0, 142.4, 137.7, 130.3, 125.4, 111.8, 105.6, 92.4; HRMS (El): m/z: calc for $\mathrm{C}_{10} \mathrm{H}_{7} \mathrm{OI}\left[\mathrm{M}^{+}\right]$: 269.9542, found: 269.9534; Column Chromatography: Hexane

2-(4-nitrophenyl)-furan (2d). ${ }^{1} \mathrm{H}$ NMR $\left(600 \mathrm{MHz}, \mathrm{CDCl}_{3}, 298 \mathrm{~K}\right)$ : $\delta \mathrm{ppm}$ $8.22(\mathrm{~d}, \mathrm{~J}=8.8 \mathrm{~Hz}, 2 \mathrm{H}), 7.77(\mathrm{~d}, \mathrm{~J}=8.8 \mathrm{~Hz}, 2 \mathrm{H}), 7.56(\mathrm{~d}, \mathrm{~J}=1.2 \mathrm{~Hz}, 1 \mathrm{H})$ $6.86(\mathrm{~d}, \mathrm{~J}=3.3 \mathrm{~Hz}, 1 \mathrm{H}), 6.54(\mathrm{dd}, \mathrm{J}=1.7,3.3 \mathrm{~Hz}, 1 \mathrm{H}) ;{ }^{13} \mathrm{C}$ NMR $(150$ $\left.\mathrm{MHz}, \mathrm{CDCl}_{3}, 298 \mathrm{~K}\right)$ : $\delta \mathrm{ppm} 151.7,146.3,144.1,136.4,124.2,123.9$ 112.4, 108.9; HRMS (El): m/z: calc for $\mathrm{C}_{10} \mathrm{H}_{7} \mathrm{NO}_{3}[\mathrm{M}+]$ : 189.0426 , found: 189.0421; Column Chromatography: 95:5 (Hex-AcOEt)

4-(furan-2-yl)benzonitrile (2e). ${ }^{1} \mathrm{H} ~ \mathrm{NMR}\left(600 \mathrm{MHz}, \mathrm{CDCl}_{3}, 298 \mathrm{~K}\right): \delta \mathrm{ppm}$ $7.73(\mathrm{~d}, \mathrm{~J}=8.3 \mathrm{~Hz}, 2 \mathrm{H}), 7.64(\mathrm{~d}, \mathrm{~J}=8.3 \mathrm{~Hz}, 2 \mathrm{H}), 7.53(\mathrm{~d}, \mathrm{~J}=1.0 \mathrm{~Hz}, 1 \mathrm{H})$ $6.81(\mathrm{~d}, \mathrm{~J}=3.5 \mathrm{~Hz}, 1 \mathrm{H}), 6.52(\mathrm{dd}, \mathrm{J}=1.6,3.3 \mathrm{~Hz}, 1 \mathrm{H}) ;{ }^{13} \mathrm{C}$ NMR $(150$ $\left.\mathrm{MHz}, \mathrm{CDCl}_{3}, 298 \mathrm{~K}\right): \delta \mathrm{ppm} 151.9,143.7,134.6,132.5,123.9,118.9$ 112.2, 110.2, 108.1; HRMS (EI): $\mathrm{m} / \mathrm{z}$ : calc for $\mathrm{C}_{11} \mathrm{H}_{7} \mathrm{NO}\left[\mathrm{M}^{+}\right]$: 169.0528 , found: 169.0520; Column Chromatography: 95:5 (Hex-AcOEt).

Methyl 4-(furan-2-yl)benzoate (2f). ${ }^{1} \mathrm{H}$ NMR $\left(600 \mathrm{MHz}, \mathrm{CDCl}_{3}, 298 \mathrm{~K}\right)$ : $\delta$ ppm $8.05(\mathrm{~d}, \mathrm{~J}=8.5 \mathrm{~Hz}, 2 \mathrm{H}), 7.72(\mathrm{~d}, \mathrm{~J}=8.5 \mathrm{~Hz}, 2 \mathrm{H}), 7.52(\mathrm{br}, 1 \mathrm{H}), 6.79$ $(\mathrm{d}, \mathrm{J}=3.4 \mathrm{~Hz}, 1 \mathrm{H}), 6.51(\mathrm{dd}, \mathrm{J}=1.8,3.4 \mathrm{~Hz}, 1 \mathrm{H}), 3.92(\mathrm{~s}, 3 \mathrm{H}) ;{ }^{13} \mathrm{C} N \mathrm{NMR}$ $\left(150 \mathrm{MHz}, \mathrm{CDCl}_{3}, 298 \mathrm{~K}\right)$ : $\delta \mathrm{ppm} 166.8,152.9,143.1,134.7,130.1$, 128.5, 123.4, 112.0, 107.2, 52.1; HRMS (EI): $\mathrm{m} / \mathrm{z}$ : calc for $\mathrm{C}_{12} \mathrm{H}_{10} \mathrm{O}_{3}\left[\mathrm{M}^{+}\right]$: 202.0630; found: 202.0627; Column Chromatography: 95:5 (Hex-AcOEt).

2-(4-methoxyphenyl)furan (2g). ${ }^{1} \mathrm{H}$ NMR $\left(600 \mathrm{MHz}, \mathrm{CDCl}_{3}, 298 \mathrm{~K}\right): \delta$ ppm $7.61(\mathrm{~d}, \mathrm{~J}=8.7 \mathrm{~Hz}, 2 \mathrm{H}), 7.43(\mathrm{~d}, \mathrm{~J}=1.0 \mathrm{~Hz}, 1 \mathrm{H}), 6.92(\mathrm{~d}, \mathrm{~J}=8.7 \mathrm{~Hz}$, $2 \mathrm{H}), 6.51(\mathrm{~d}, \mathrm{~J}=3.4 \mathrm{~Hz}, 1 \mathrm{H}), 6.45(\mathrm{dd}, \mathrm{J}=1.7,3.1 \mathrm{~Hz}, 1 \mathrm{H}), 384(\mathrm{~s}, 3 \mathrm{H})$; ${ }^{13} \mathrm{C}$ NMR $\left(150 \mathrm{MHz}, \mathrm{CDCl}_{3}, 298 \mathrm{~K}\right)$ : $\delta \mathrm{ppm} 159.0,154.0,141.4,125.2$, 124.1, 114.1, 111.5, 103.4, 55.3; HRMS (EI): $\mathrm{m} / \mathrm{z}$ : calcd for $\mathrm{C}_{11} \mathrm{H}_{10} \mathrm{O}_{2}$ 
$\left[\mathrm{M}^{+}\right]$: 174.0681, found: 174.0683; Column Chromatography: 95:5 (HexAcOEt).

2-(3-nitrophenyl)furan (2h). ${ }^{1} \mathrm{H}$ NMR $\left(600 \mathrm{MHz}, \mathrm{CDCl}_{3}, 298 \mathrm{~K}\right): \delta \mathrm{ppm}$ $8.49(\mathrm{~s}, 1 \mathrm{H}), 8.08(\mathrm{dt}, \mathrm{J}=8.0,1.0 \mathrm{~Hz}, 1 \mathrm{H}), 7.95(\mathrm{~d}, \mathrm{~J}=7.8 \mathrm{~Hz}, 1 \mathrm{H}), 7.55$ $(\mathrm{d}, \mathrm{J}=8.0 \mathrm{~Hz}, 1 \mathrm{H}), 7.53(\mathrm{~d}, \mathrm{~J}=0.6 \mathrm{~Hz}, 1 \mathrm{H}), 6.81(\mathrm{~d}, \mathrm{~J}=3.6 \mathrm{~Hz}, 1 \mathrm{H}), 6.53$ $(\mathrm{m}, 1 \mathrm{H}) ;{ }^{13} \mathrm{C}$ NMR $\left(180 \mathrm{MHz}, \mathrm{CDCl}_{3}, 298 \mathrm{~K}\right): \delta \mathrm{ppm} 151.4,148.5,143.2$, 132.2, 129.7, 129.2, 121.6, 118.4, 112.1, 107.2; HRMS (El): m/z: calcd for $\mathrm{C}_{10} \mathrm{H}_{7} \mathrm{NO}_{3}\left[\mathrm{M}^{+}\right]$: 189.0426, found: 189.0428; Column Chromatography: 95:5 (Hex-AcOEt)

2-(2-nitrophenyl)furan (2i). ${ }^{1} \mathrm{H}$ NMR $\left(600 \mathrm{MHz}, \mathrm{CDCl}_{3}, 298 \mathrm{~K}\right): \delta \mathrm{ppm}$ $7.71(\mathrm{~d}, \mathrm{~J}=7.8 \mathrm{~Hz}, 1 \mathrm{H}), 7.68(\mathrm{~d}, \mathrm{~J}=8.1 \mathrm{~Hz}, 1 \mathrm{H}), 7.58(\mathrm{t}, \mathrm{J}=7.7 \mathrm{~Hz}, 1 \mathrm{H})$, $7.51(\mathrm{~d}, \mathrm{~J}=1.0 \mathrm{~Hz}, 1 \mathrm{H}), 7.41(\mathrm{t}, \mathrm{J}=7.7 \mathrm{~Hz}, 1 \mathrm{H}), 6.67(\mathrm{~d}, \mathrm{~J}=3.4 \mathrm{~Hz}, 1 \mathrm{H})$ $6.50(\mathrm{dd}, \mathrm{J}=3.2,1.8 \mathrm{~Hz}) ;{ }^{13} \mathrm{C}$ NMR $\left(180 \mathrm{MHz}, \mathrm{CDCl}_{3}, 298 \mathrm{~K}\right): \delta \mathrm{ppm}$ 148.4, 147.4, 143.9, 132.0, 128.9, 128.3, 124.1, 123.9, 111.9, 109.7; HRMS (El): $\mathrm{m} / \mathrm{z}$ : calcd for $\mathrm{C}_{10} \mathrm{H}_{7} \mathrm{NO}_{3}\left[\mathrm{M}^{+}\right]$: 189.0426, found: 189.0427 ; Column Chromatography: 95:5 (Hex-AcOEt).

2-(4-(trifluoromethyl)phenyl)furan (2j). ${ }^{1} \mathrm{H} ~ \mathrm{NMR}\left(600 \mathrm{MHz}, \mathrm{CDCl}_{3}, 298 \mathrm{~K}\right)$ : $\delta$ ppm $7.76(\mathrm{~d}, \mathrm{~J}=8.3 \mathrm{~Hz}, 2 \mathrm{H}), 7.63(\mathrm{~d}, \mathrm{~J}=8.3 \mathrm{~Hz}, 2 \mathrm{H}), 7.52(\mathrm{~s}, 1 \mathrm{H})$, $6.77(\mathrm{~d}, \mathrm{~J}=3.3 \mathrm{~Hz}, 1 \mathrm{H}), 6.52(\mathrm{~m}, 1 \mathrm{H}) ;{ }^{13} \mathrm{C} \mathrm{NMR}\left(180 \mathrm{MHz}, \mathrm{CDCl}_{3}, 298\right.$ $\mathrm{K}): \delta$ ppm 152.4, 143.0, 133.9, 125.7, 125.6, 123.7, 111.9, 106.9; HRMS (El): $\mathrm{m} / \mathrm{z}$ : calcd for $\mathrm{C}_{11} \mathrm{H}_{7} \mathrm{OF}_{3}\left[\mathrm{M}^{+}\right]$: 212.0449, found: 212.0455; Column Chromatography: Hexane.

2-(3,5-di-tert-butylphenyl)furan (2k). ${ }^{1} \mathrm{H}$ NMR $\left(600 \mathrm{MHz}, \mathrm{CDCl}_{3}, 298 \mathrm{~K}\right): \delta$ ppm 7.52 (d, J = $1.53 \mathrm{~Hz}, 2 \mathrm{H}), 7.46(\mathrm{~s}, 1 \mathrm{H}), 7.34(\mathrm{~s}, 1 \mathrm{H}), 6.64(\mathrm{~d}, \mathrm{~J}=$ $3.10 \mathrm{~Hz}, 1 \mathrm{H}), 6.47$ (dd, J = 3.19, $1.72,1 \mathrm{H}), 1.35(\mathrm{~s}, 18 \mathrm{H}) ;{ }^{13} \mathrm{C}$ NMR $(180$ $\left.\mathrm{MHz}, \mathrm{CDCl}_{3}, 298 \mathrm{~K}\right): \delta \mathrm{ppm} 154.9,151.1,141.7,130.1,121.7,118.3$, 111.6, 105.5, 34.9, 31.4; HRMS (ESI): $\mathrm{m} / \mathrm{z}$ : calc for $\mathrm{C}_{18} \mathrm{H}_{24} \mathrm{ONa}\left[\mathrm{M}+\mathrm{Na}^{+}\right]$ 279.1725; found: 279.1720; Column Chromatography: Hexane.

2-(4-azidophenyl)furan (2l). ${ }^{1} \mathrm{H}$ NMR $\left(600 \mathrm{MHz}, \mathrm{CDCl}_{3}, 298 \mathrm{~K}\right): \delta \mathrm{ppm}$ $7.65(\mathrm{~d}, \mathrm{~J}=8.5 \mathrm{~Hz}, 2 \mathrm{H}), 7.47(\mathrm{~d}, \mathrm{~J}=0.7 \mathrm{~Hz}, 1 \mathrm{H}), 7.04(\mathrm{~d}, \mathrm{~J}=8.5 \mathrm{~Hz}, 2 \mathrm{H})$, $6.62(\mathrm{~d}, \mathrm{~J}=3.3 \mathrm{~Hz}, 1 \mathrm{H}), 6.48(\mathrm{dd}, \mathrm{J}=1.7,3.1 \mathrm{~Hz}, 1 \mathrm{H}) ;{ }^{13} \mathrm{C}$ NMR $(150$ $\left.\mathrm{MHz}, \mathrm{CDCl}_{3}, 298 \mathrm{~K}\right)$ : $\delta$ ppm 153.1, 142.0, 138.6, 127.7, 125.1, 119.2, 111.7, 104.8; HRMS (El): m/z: calc for $\mathrm{C}_{10} \mathrm{H}_{7} \mathrm{~N}_{3} \mathrm{O}\left[\mathrm{M}^{+}\right]$: 185.0589; found: 185.0593; Column Chromatography: 98:2 (Hex-AcOEt)

((4-(furan-2-yl)phenyl)ethynyl)trimethylsilane (2m). ${ }^{1} \mathrm{H}$ NMR $(600 \mathrm{MHz}$, $\left.\mathrm{CDCl}_{3}, 298 \mathrm{~K}\right): \delta$ ppm $7.61(\mathrm{~d}, \mathrm{~J}=8.2 \mathrm{~Hz}, 2 \mathrm{H}), 7.48(\mathrm{~m}, 3 \mathrm{H}), 6.69$ (d, J = $3.3 \mathrm{~Hz}, 1 \mathrm{H}), 6.48$ (dd, J = 1.6, $2.9 \mathrm{~Hz}, 1 \mathrm{H}), 0.27(\mathrm{~s}, 9 \mathrm{H}) ;{ }^{13} \mathrm{C}$ NMR $(150$ $\left.\mathrm{MHz}_{\mathrm{CDCl}}, 298 \mathrm{~K}\right): \delta \mathrm{ppm} 153.2,142.5,132.3,130.6,123.3,121.6$ 111.8, 106.0, 105.0, 94.6; HRMS (El): $\mathrm{m} / \mathrm{z}$ : calc for $\mathrm{C}_{15} \mathrm{H}_{16} \mathrm{OSi}\left[\mathrm{M}^{+}\right]$: 240.0970; found: 240.0978; Column Chromatography: Hexane.

1-(3-(furan-2-yl)phenyl)ethan-1-one (2n). ${ }^{1} \mathrm{H}$ NMR $\left(600 \mathrm{MHz}, \mathrm{CDCl}_{3}, 298\right.$ K): $\delta$ ppm $8.24(\mathrm{~s}, 1 \mathrm{H}), 7.85(\mathrm{~d}, \mathrm{~J}=7.7 \mathrm{~Hz}, 1 \mathrm{H}), 7.83(\mathrm{~d}, \mathrm{~J}=7.7 \mathrm{~Hz}, 1 \mathrm{H})$, $7,50(\mathrm{~m}, 1 \mathrm{H}), 7.47(\mathrm{t}, \mathrm{J}=7.7 \mathrm{~Hz}, 1 \mathrm{H}), 6.74(\mathrm{~d}, \mathrm{~J}=3.2 \mathrm{~Hz}, 1 \mathrm{H}), 6.50$ (dd, J $=1.6,3.2 \mathrm{~Hz}, 1 \mathrm{H}), 2.64(\mathrm{~s}, 3 \mathrm{H}) ;{ }^{13} \mathrm{C} \mathrm{NMR}\left(150 \mathrm{MHz}, \mathrm{CDCl}_{3}, 298 \mathrm{~K}\right): \delta$ ppm 198.1, 152.8, 142.5, 137.3, 131.2, 128.9, 128.0, 127.0, 123.4, 111.8 105.9, 26.8; HRMS (ESI): m/z: calc for $\mathrm{C}_{12} \mathrm{H}_{10} \mathrm{O}_{2} \mathrm{Na}\left[\mathrm{M}+\mathrm{Na}^{+}\right]$: 209.0578, found: 209.0572; Column Chromatography: 90:10 (Hex-AcOEt).

2-(4-chlorophenyl)thiophene (20). ${ }^{1} \mathrm{H}$ NMR $\left(600 \mathrm{MHz}, \mathrm{CDCl}_{3}, 298 \mathrm{~K}\right): \delta$ ppm $7.54(\mathrm{~d}, \mathrm{~J}=8.4 \mathrm{~Hz}, 2 \mathrm{H}), 7.35(\mathrm{~d}, \mathrm{~J}=8.4 \mathrm{~Hz}, 2 \mathrm{H}), 7,30-7.28(\mathrm{~m}, 2 \mathrm{H})$ 7.08 (dd, J = 3.9, $4.7 \mathrm{~Hz}, 1 \mathrm{H}) ;{ }^{13} \mathrm{C}$ NMR $\left(150 \mathrm{MHz}, \mathrm{CDCl}_{3}, 298 \mathrm{~K}\right): \delta \mathrm{ppm}$ 143.1, 133.2, 132.9, 129.0, 128.1, 127.1, 125.2, 123.4; HRMS (EI): m/z: calc for $\mathrm{C}_{10} \mathrm{H}_{7} \mathrm{~S}^{35} \mathrm{Cl}\left[\mathrm{M}^{+}\right]$: 193.9957 , found: 193.9956 / calc for $\mathrm{C}_{10} \mathrm{H}_{7} \mathrm{~S}^{37} \mathrm{Cl}$ $\left[\mathrm{M}^{+}\right]$: 195.9927, found: 195.9925; Column Chromatography: 95:5 (HexAcOEt). 4-(thiophen-2-yl)benzonitrile (2p). ${ }^{1} \mathrm{H}$ NMR $\left(600 \mathrm{MHz}, \mathrm{CDCl}_{3}, 298 \mathrm{~K}\right): \delta$ ppm 7.69 (d, J = 8.7 Hz, 2H), 7.64 (d, J = 8.7 Hz, 2H), 7.42 (d, J = 3.6 Hz, $1 \mathrm{H}), 7.40(\mathrm{~d}, \mathrm{~J}=5.0 \mathrm{~Hz}, 1 \mathrm{H}), 7.13(\mathrm{dd}, \mathrm{J}=3.9,4.9 \mathrm{~Hz}, 1 \mathrm{H}) ;{ }^{13} \mathrm{C} N M R$ $\left(150 \mathrm{MHz}, \mathrm{CDCl}_{3}, 298 \mathrm{~K}\right): \delta \mathrm{ppm} 142.0,138.6,132.7,128.5,127.0$, 126.0, 125.0, 118.8, 110.5; HRMS (El): m/z: calc for $\mathrm{C} 11 \mathrm{H} 7 \mathrm{NS}[\mathrm{M}+$ ]: 185.0299, found: 185.0302; Column Chromatography: 95:5 (Hex-AcOEt).

Methyl 4-(thiophen-2-yl)benzoate (2q). ${ }^{1} \mathrm{H}$ NMR $\left(600 \mathrm{MHz}, \mathrm{CDCl}_{3}, 298\right.$ $\mathrm{K})$ : $\delta$ ppm $8.04(\mathrm{~d}, \mathrm{~J}=7.8 \mathrm{~Hz}, 2 \mathrm{H}), 7.67(\mathrm{~d}, \mathrm{~J}=7.8 \mathrm{~Hz}, 2 \mathrm{H}), 7.41$ (d, J = $3.5 \mathrm{~Hz}, 1 \mathrm{H}), 7.36(\mathrm{~d}, \mathrm{~J}=5.1 \mathrm{~Hz}, 1 \mathrm{H}), 7.11(\mathrm{dd}, \mathrm{J}=3.7,4.9 \mathrm{~Hz}, 1 \mathrm{H}) ;{ }^{13} \mathrm{C}$ NMR (150 MHz, $\left.\mathrm{CDCl}_{3}, 298 \mathrm{~K}\right)$ : $\delta$ ppm 166.7, 143.1, 138.6, 130.2, 128.3, 126.2, 125.5, 124.5, 52.1; HRMS (El): $\mathrm{m} / \mathrm{z}$ : calc for $\mathrm{C}_{12} \mathrm{H}_{10} \mathrm{O}_{2} \mathrm{~S}[\mathrm{M}+$ ]: 218.0402, found: 218.0399; Column Chromatography: 95:5 (Hex-AcOEt).

tert-butyl 2-(4-cyanophenyl)-1 H-pyrrole-1-carboxylate (2r). ${ }^{1} \mathrm{H}$ NMR $(600$ $\left.\mathrm{MHz}, \mathrm{CDCl}_{3}, 298 \mathrm{~K}\right)$ : $\delta$ ppm $7.62(\mathrm{~d}, \mathrm{~J}=8.3,2 \mathrm{H}), 7.45(\mathrm{~d}, \mathrm{~J}=8.2,2 \mathrm{H})$, 7.38 (dd, $\mathrm{J}=1.8,3.2,1 \mathrm{H}), 6.27(\mathrm{dd}, \mathrm{J}=1.8,3.3,1 \mathrm{H}), 6.25(\mathrm{dd}, \mathrm{J}=3.3$, $1 \mathrm{H}), 1.41(\mathrm{~s}, 9 \mathrm{H}) ;{ }^{13} \mathrm{C}$ NMR $\left(150 \mathrm{MHz} \mathrm{CDCl}_{3}, 298 \mathrm{~K}\right): \delta \mathrm{ppm} 148.8$, 138.7, 133.0, 131.2, 129.4, 123.8, 118.8, 116.0, 110.9, 110.4, 84.2, 27.6; HRMS (ESI): m/z: calcd for $\mathrm{C}_{16} \mathrm{H}_{16} \mathrm{~N}_{2} \mathrm{O}_{2} \mathrm{Na}\left[\mathrm{M}^{+}\right]$: 291.1109, found: 291.1104; Column Chromatography: 95:5 (Hex-AcOEt).

tert-butyl 2-(4-(methoxycarbonyl)phenyl)-1H-pyrrole-1-carboxylate (2s). ${ }^{1} \mathrm{H}$ NMR $\left(600 \mathrm{MHz} \mathrm{CDCl}_{3}, 298 \mathrm{~K}\right): \delta \mathrm{ppm} 8.02(\mathrm{~d}, \mathrm{~J}=8.3,2 \mathrm{H}), 7.42(\mathrm{~d}, \mathrm{~J}$ $=8.3,2 \mathrm{H}), 7.38(\mathrm{dd}, \mathrm{J}=1.8,3.1,1 \mathrm{H}), 6.26(\mathrm{dd}, \mathrm{J}=1.8,3.2,1 \mathrm{H}), 6.24(\mathrm{dd}$, $\mathrm{J}=3.3,1 \mathrm{H}), 3.92(\mathrm{~s}, 3 \mathrm{H}), 1.37(\mathrm{~s}, 9 \mathrm{H}) ;{ }^{13} \mathrm{C} \mathrm{NMR}\left(150 \mathrm{MHz}, \mathrm{CDCl}_{3}, 298\right.$ K): $\delta$ ppm 166.9, 149.1, 138.9, 133.9, 128.9, 128.5, 123.4, 115.4, 110.8, 84.0, 52.0, 27.6; HRMS (El): m/z: calcd for $\mathrm{C}_{17} \mathrm{H}_{19} \mathrm{O}_{4} \mathrm{NNa}\left[\mathrm{M}^{+}\right]$: 324.1212 , found: 324.1205; Column Chromatography: 95:5 (Hex-AcOEt).

4-chloro-1,1'-biphenyl (2t). ${ }^{1} \mathrm{H}$ NMR (600 MHz, $\left.\mathrm{CDCl}_{3}, 298 \mathrm{~K}\right): \delta \mathrm{ppm}$ 7.57-7.52 (m, 4H), 7.46-7.37 (m, 5H); ${ }^{13} \mathrm{C} \mathrm{NMR} \mathrm{(150} \mathrm{MHz,} \mathrm{CDCl} 3,298$ $\mathrm{K}): \delta$ ppm 140.0, 139.6, 133.3, 128.9, 128.9, 128.4, 127.6, 127.0; HRMS (El): $\mathrm{m} / \mathrm{z}$ : calc for $\mathrm{C}_{12} \mathrm{H}_{9} \mathrm{OCl}[\mathrm{M}+]$ : 188.0393, found: 188.0388; Column Chromatography: 90:10 (Hex-AcOEt).

[1,1'-biphenyl]-4-carbonitrile (2u). ${ }^{1} \mathrm{H}$ NMR (600 MHz, $\left.\mathrm{CDCl}_{3}, 298 \mathrm{~K}\right): \delta$ ppm 7.73 (d, J = 8.0 Hz, 2H), 7.69 (d, J = 8.0 Hz, 2H), 7.59 (d, J = 7.2 Hz, $2 \mathrm{H}), 7.49$ (t, J = 7.4 Hz, 2H), 7.43 (t, J = 7.4 Hz, $1 \mathrm{H}) ;{ }^{13} \mathrm{C} \mathrm{NMR}(150 \mathrm{MHz}$, $\left.\mathrm{CDCl}_{3}, 298 \mathrm{~K}\right)$ : $\delta \mathrm{ppm} 145.6,139.1,132.6,129.1,128.6,127.7,127.1$, 118.9, 110.9; HRMS (El): m/z: calc for $\mathrm{C}_{13} \mathrm{H}_{9} \mathrm{~N}\left[\mathrm{M}^{+}\right]$: 179.0735 , found: 179.0729; Column Chromatography: 90:10 (Hex-AcOEt).

Methyl [1,1'-biphenyl]-4-carboxylate (2v). ${ }^{1} \mathrm{H}$ NMR $\left(600 \mathrm{MHz}, \mathrm{CDCl}_{3}, 298\right.$ $\mathrm{K}): \delta \mathrm{ppm} 8.11(\mathrm{~d}, \mathrm{~J}=8.4 \mathrm{~Hz}, 2 \mathrm{H}), 7.67(\mathrm{~d}, \mathrm{~J}=8.4 \mathrm{~Hz}, 2 \mathrm{H}), 7.63(\mathrm{~d}, \mathrm{~J}=$ $7.3 \mathrm{~Hz}, 2 \mathrm{H}), 7.47$ (t, J = 7.6 Hz, 2H), 7.40 (t, J = 7.6 Hz, 1H), $3.95(\mathrm{~s}, 3 \mathrm{H})$; ${ }^{13} \mathrm{C}$ NMR $\left(150 \mathrm{MHz} \mathrm{CDCl}_{3}, 298 \mathrm{~K}\right): \delta$ ppm 167.0, 145.6, 140.0, 130.1 128.9, 128.1, 127.2, 127.0, 52.1; HRMS (EI): m/z: calc for $\mathrm{C}_{14} \mathrm{H}_{12} \mathrm{O}_{2}\left[\mathrm{M}^{+}\right]$: 212.0837, found: 212.0834; Column Chromatography: 90:10 (HexAcOEt).

4-nitro-1,1'-biphenyl (2w). ${ }^{1} \mathrm{H}$ NMR (500 MHz, $\left.\mathrm{CDCl}_{3}, 298 \mathrm{~K}\right)$ : $\delta$ ppm 8.30 (d, $J=8.7,2 \mathrm{H}$ ), 7.74 (d, $J=8.7,2 \mathrm{H}$ ), 7.74 (dd, $J=1.4,7.3,2 \mathrm{H}), 7.50$ (dd, $J=7.1,7.5,2 \mathrm{H}), 7.45(\mathrm{dd}, J=7.3,7.3,1 \mathrm{H}) ;{ }^{13} \mathrm{C} \mathrm{NMR}\left(150 \mathrm{MHz}, \mathrm{CDCl}_{3}\right.$, 298 K): $\delta$ ppm 147.7, 147.1, 138.8, 129.3, 129.0, 127.9, 127.5, 124.2 Column Chromatography: 90:10 (hexane:EtOAc)

4-bromo-1,1'-biphenyl (2x). ${ }^{1} \mathrm{H}$ NMR (500 MHz, $\left.\mathrm{CDCl}_{3}, 298 \mathrm{~K}\right): \delta \mathrm{ppm}$ 7.58-7.54 (m, 4H), 7.48-7.42 (m, 4H), 7.39-7.35 (m, 1H); ${ }^{13} \mathrm{C}$ NMR $(150$ $\left.\mathrm{MHz}, \mathrm{CDCl}_{3}, 298 \mathrm{~K}\right): \delta$ ppm 140.2, 140.1, 132.0, 129.0, 128.9, 127.8, 127.1, 121.6; Column Chromatography: $n$-hexane.

2-nitro-1,1'-biphenyl (2aa). ${ }^{1} \mathrm{H}$ NMR $\left(600 \mathrm{MHz}, \mathrm{CDCl}_{3}, 298 \mathrm{~K}\right): \delta \mathrm{ppm}$ $7.86(\mathrm{~d}, \mathrm{~J}=8.1,1 \mathrm{H}), 7.63(\mathrm{dd}, \mathrm{J}=7.5,7.5,1 \mathrm{H}), 7.49(\mathrm{dd}, \mathrm{J}=7.7,7.7$, 
$1 \mathrm{H}), 7.47-7.39(\mathrm{~m}, 4 \mathrm{H}), 7.33(\mathrm{~d}, \mathrm{~J}=7.1,1 \mathrm{H}) ;{ }^{13} \mathrm{C} \mathrm{NMR}\left(150 \mathrm{MHz}, \mathrm{CDCl}_{3}\right.$ $298 \mathrm{~K}): \delta \mathrm{ppm} 137.4,136.4,132.4,132.0,128.8,128.3,128.2,127.9$, 124.2; Column Chromatography: 95:5 (hexane:EtOAc)

4'-chloro-2,5-dimethyl-1,1'-biphenyl (2ab). ${ }^{1} \mathrm{H} \mathrm{NMR}\left(500 \mathrm{MHz}, \mathrm{CDCl}_{3}\right.$, $298 \mathrm{~K}$ ): $\delta \mathrm{ppm} 7.37$ (d, $J=8.5,2 \mathrm{H}), 7.24$ (d, $J=8.5,2 \mathrm{H}$ ), 7.15 (d, $J=7.8$, $1 \mathrm{H}), 7.08$ (dd, $J=1.3,7.7,1 \mathrm{H}), 7.01(\mathrm{~d}, J=1.3,1 \mathrm{H}), 2.34(\mathrm{~s}, 3 \mathrm{H}), 2.21$ (s $3 \mathrm{H}) ;{ }^{13} \mathrm{C}$ NMR $\left(150 \mathrm{MHz}, \mathrm{CDCl}_{3}, 298 \mathrm{~K}\right): \delta \mathrm{ppm} 140.6,135.5,132.9$, 132.2, 130.6, 130.5, 128.4, 128.3, 21.0, 20.0; Column Chromatography: hexane.

4'-chloro-2,4,6-trimethyl-1,1'-biphenyl (2ac). ${ }^{1} \mathrm{H}$ NMR $\left(500 \mathrm{MHz}, \mathrm{CDCl}_{3}\right.$, $298 \mathrm{~K}$ ): $\delta \mathrm{ppm} 7.40(\mathrm{~d}, J=8.5,2 \mathrm{H}), 7.09(\mathrm{~d}, J=8.5,2 \mathrm{H}), 7.01(\mathrm{~s}, 2 \mathrm{H})$, $2.34(\mathrm{~s}, 3 \mathrm{H}), 2.00(\mathrm{~s}, 6 \mathrm{H}) ;{ }^{13} \mathrm{C} \mathrm{NMR}\left(150 \mathrm{MHz}, \mathrm{CDCl}_{3}, 298 \mathrm{~K}\right): \delta \mathrm{ppm}$ 139.6, 137.8, 137.1, 136.0, 132.5, 130.8, 128.8, 128.3, 21.2, 20.9 Column Chromatography: hexane.

4-(3-methyl-1,4-dioxo-1,4-dihydronaphthalen-2-yl)benzonitrile (3). $\quad{ }^{1} \mathrm{H}$ NMR $\left(600 \mathrm{MHz}, \mathrm{CDCl}_{3}, 298 \mathrm{~K}\right)$ : $\delta$ ppm 8.16-8,13 (m, 1H), 8.11-8.08 (m, $1 \mathrm{H}), 7.76(\mathrm{~m}, 4 \mathrm{H}), 7.36(\mathrm{~d}, \mathrm{~J}=8.1 \mathrm{~Hz}, 2 \mathrm{H}), 2.06(\mathrm{~s}, 3 \mathrm{H}) ;{ }^{13} \mathrm{C}$ NMR $(150$ $\left.\mathrm{MHz}, \mathrm{CDCl}_{3}, 298 \mathrm{~K}\right): \delta$ ppm 185.0, 183.4, 144.8, 144.4, 138.4, 133.9, 133.9, 131.9, 131.7, 130.3, 126.6, 126.4, 118.4, 112.5, 14.6; HRMS (EI): $\mathrm{m} / \mathrm{z}$ : calc for $\mathrm{C}_{18} \mathrm{H}_{11} \mathrm{NO}_{2}\left[\mathrm{M}^{+}\right]$: 273.0790, found: 273.0789; Column Chromatography: 90:10 (Hex-AcOEt)

2-butyl-6-(furan-2-yl)-1H-benzo[de]isoquinoline-1,3(2H)-dione (4) (Very sensitive). ${ }^{1} \mathrm{H}$ NMR (500 MHz, $\mathrm{CDCl}_{3}, 298 \mathrm{~K}$ ): $\delta$ ppm 8.87 (dd, $\mathrm{J}=0.9$, $8.4 \mathrm{~Hz}, 1 \mathrm{H}), 8.86(\mathrm{dd}, \mathrm{J}=0.9,7.2 \mathrm{~Hz}, 1 \mathrm{H}), 8.60(\mathrm{~d}, \mathrm{~J}=7.7 \mathrm{~Hz}, 1 \mathrm{H}), 7.98$ $(\mathrm{d}, \mathrm{J}=7.7 \mathrm{~Hz}, 1 \mathrm{H}), 7.78$ (dd, J = 7.4, 8.6 Hz, 1H), $7.72(\mathrm{~d}, \mathrm{~J}=1.1 \mathrm{~Hz}, 1 \mathrm{H})$ $6.95(\mathrm{~d}, \mathrm{~J}=3.4 \mathrm{~Hz}, 1 \mathrm{H}), 6.66$ (dd, J = 1.8, $3.4 \mathrm{~Hz}, 1 \mathrm{H}), 4.19$ (t, J = $7.5 \mathrm{~Hz}$ $2 \mathrm{H}), 1.76-1.70(\mathrm{~m}, 2 \mathrm{H}), 1.50-1.42(\mathrm{~m}, 2 \mathrm{H}), 0.98(\mathrm{t}, \mathrm{J}=7.3,3 \mathrm{H}) ;{ }^{13} \mathrm{C} N M R$ $\left(100 \mathrm{MHz}, \mathrm{CDCl}_{3}, 298 \mathrm{~K}\right): \delta \mathrm{ppm} 164.3,163.9,152.0,144.2134 .1$, $133.8,132.2,131.2,130.8,128.2,127.2,125.9,123.1,121.8,112.2$, 112.1, 40.3, 30.2, 20.4, 13.8; HRMS (ESI): m/z: calc for $\mathrm{C}_{20} \mathrm{H}_{17} \mathrm{NO}_{3} \mathrm{Na}$ $\left[\mathrm{M}+\mathrm{Na}^{+}\right]$: 342.1106; found: 342.1107; Column Chromatography: 95:5 (Hex-AcOEt)

2-(5-(2-butyl-1,3-dioxo-2,3-dihydro-1H-benzo[de]isoquinolin-6yl)thiophen-2-yl)acetonitrile (5). ${ }^{1} \mathrm{H}$ NMR $\left(500 \mathrm{MHz}, \mathrm{CDCl}_{3}, 298 \mathrm{~K}\right): \delta$ ppm $8.66(\mathrm{dd}, \mathrm{J}=1.0,7.2 \mathrm{~Hz}, 1 \mathrm{H}), 8.86(\mathrm{~d}, \mathrm{~J}=7.6 \mathrm{~Hz}, 1 \mathrm{H}), 8.57(\mathrm{~d}, \mathrm{~J}=0.9$, $8.5 \mathrm{~Hz}, 1 \mathrm{H}), 7.80-7.77(\mathrm{~m}, 2 \mathrm{H}), 7.23-7.21(\mathrm{~m}, 2 \mathrm{H}), 4.22-4.19(\mathrm{~m}, 2 \mathrm{H})$, $4.03(\mathrm{~s}, 2 \mathrm{H}), 1.76-1.70(\mathrm{~m}, 2 \mathrm{H}), 1.50-1.42(\mathrm{~m}, 2 \mathrm{H}), 0.99(\mathrm{t}, \mathrm{J}=7.4,3 \mathrm{H})$; ${ }^{13} \mathrm{C}$ NMR $\left(125 \mathrm{MHz}, \mathrm{CDCl}_{3}, 298 \mathrm{~K}\right): \delta \mathrm{ppm} 164.1,163.8,140.5,138.0$, $133.2,131.8,131.5,130.5,129.9,128.9,128.8,128.7,128.0,127.4$, 123.1, 122.5, 40.3, 30.2, 20.4, 18.9, 13.8; HRMS (ESI): m/z: calc for $\mathrm{C}_{22} \mathrm{H}_{18} \mathrm{~N}_{2} \mathrm{O}_{2} \mathrm{SNa} \quad\left[\mathrm{M}+\mathrm{Na}^{+}\right]:$397.0987; found: 397.0980; Column Chromatography: 90:10 (Hex-AcOEt)

4-(4-(3,3,4,4,5,5-hexafluoro-2-(2-methylthiophen-3-yl)cyclopent-1-en-1yl)-5-methylthiophen-2-yl)benzonitrile (6). ${ }^{1} \mathrm{H}$ NMR $\left(600 \mathrm{MHz}, \mathrm{CDCl}_{3}, 298\right.$ $\mathrm{K})$ : $\delta \mathrm{ppm} 7.66(\mathrm{~d}, \mathrm{~J}=8.6 \mathrm{~Hz}, 2 \mathrm{H}), 7.61(\mathrm{~d}, \mathrm{~J}=7.9 \mathrm{~Hz}, 2 \mathrm{H}), 7.36(\mathrm{~s}, 1 \mathrm{H})$, $7.19(\mathrm{~d}, \mathrm{~J}=5.7 \mathrm{~Hz}, 1 \mathrm{H}), 7.06(\mathrm{~d}, \mathrm{~J}=5.0 \mathrm{~Hz}, 1 \mathrm{H}), 1.97(\mathrm{~s}, 3 \mathrm{H}), 1.93$ (s, $3 \mathrm{H}) ;{ }^{13} \mathrm{C}$ NMR $\left(150 \mathrm{MHz}, \mathrm{CDCl}_{3}, 298 \mathrm{~K}\right): \delta \mathrm{ppm} 143.4,141.8,139.8$, $137.5,132.8,132.2,128.4,127.1,126.6,126.4,125.8,124.6,123.9$, 118.6, 116.0, 111.0, 14.5, 14.3; HRMS (EI): $\mathrm{m} / \mathrm{z}$ : calc for $\mathrm{C}_{22} \mathrm{H}_{13} \mathrm{NS}_{2} \mathrm{~F}_{6} \mathrm{Na}$ [M+Na+]: 492.0291; found: 492.0294; Column Chromatography: 95:5 (Hex-AcOEt)

\section{Acknowledgements}

Authors thank Julio Rodríguez-López for his technical support with the NMR. This work has been funded by Ministerio de Economía y Competitividad-MINECO (CTQ2015-73234-JIN and
CTQ2014-56362-C2-1-P), co-financed by the European Regional Development Fund (ERDF). D. M. M. thanks MINECO for a FPI fellowship.

Keywords: Radical reactions $\cdot \mathrm{C}-\mathrm{C}$ coupling $\cdot$ Heterocycles $•$ Diazo compounds $\cdot$ Dyes/pigments

[1] a) J. Hassan, M. Sevignon, C. Gozzi, E. Schulz, M. Lemaire, Chem Rev., 2002, 102, 1359-1470, and references therein; b) J.-P. Corbet, G. Mignani, Chem. Rev. 2006, 106, 2651-2710.

[2] P. Anastas, N. Eghbali, Chem. Soc. Rev. 2010, 39, 301-312.

[3] a) C. E. Garrett, K. Prasad, Adv. Synth. Catal. 2004, 346, 889-900; b) J. C. Hermann, Y. Chen, C. Wartchow, J. Menke, L. Gao, S. K. Gleason, N.-E. Haynes, N. Scott, A. Petersen, S. Gabriel, B. Vu, K. M. George, A Narayanan, S. H. Li, H. Qian, N. Beatini, L. Niu, Q.-F. Gan, ACS Med. Chem. Lett. 2013, 4, 197-200.

[4] a) A. J. Eberhart, H. Shrives, Y. Zhang, A. Carrër, A. V. S.Parry, D. J. Tate, M. L. Turner, D. J. Procter, Chem. Sci. 2016, 7, 1281-1285; b) F. C. Krebs, R. B. Nyberg, M. Jørgensen, Chem. Mater. 2004, 16, 1313 1318.

[5] a) J. Hofmann, M. R. Heinrich, Tetrahedron Lett. 2016, 57, 4334-4340 b) W. R. Bowman, J. M. D. Storey, Chem. Soc. Rev. 2007, 36, 1803 1822; c) H. Bonin, M. Sauthier, F.-X. Felpin, Adv. Synth. Catal. 2014 356, 645-671; d) R. A. Rossi, A. B. Pierini, A. B. Peñéñory, Chem. Rev. 2003, 103, 71-168

[6] For some examples of mild, transition metal-free generation of aryl radicals, see: a) D. Hari, P. Schroll, B. König, J. Am. Chem. Soc. 2012 134, 2958-2961; b) F. P. Crisóstomo, T. Martín, R. Carrillo, Angew. Chem. 2014, 126, 2213-2217; Angew. Chem., Int. Ed. 2014, 53, 2181. 2185; c) S. Shaaban, A. Jolit, D. Petkova, N. Maulide, Chem. Commun. 2015, 51, 13902-13905; d) M. D. Perretti, D. M. Monzón, F. P Crisóstomo, V. S. Martín, R. Carrillo, Chem. Commun. 2016, 52, 9036 9039; e) T. Amaya, D. Hata, T. Moriuchi, T. Hirao, Chem. Eur. J. 2015 21, 16427-16433; f) M. Hartmann, C. G. Daniliuc, A. Studer, Chem. Commun. 2015, 51, 3121-3123; g) M.-J. Bu, G.-P. Lua, C. Cai, Org. Chem. Front., 2016, 3, 630-634.

[7] E. Bamberger, Ber. Dtsch. Chem. Ges. 1896, 29, 446-473.

[8] a) E. Müller, H. Haiss, Chem. Ber. 1962, 95, 1255-1263; b) T. Kauffmann, H. O. Friestad, H. Henkler, Liebigs Ann. Chem. 1960, 634, 64-78.

[9] a) M. Gomberg, W. E. Bachmann, J. Am. Chem. Soc. 1924, 46, 2339 2343; b) C. Rüchardt, E. Merz, Tetrahedron Lett. 1964, 36, 2431-2436.

[10] Augood and Williams described the Gomberg-Bachmann reaction almost as useless in their review on homolytic aromatic arylations: "The products of reaction are usually very tarry and the yields of biaryl are low, ca. 10-20 per cent of the amine, with the formation of large quantities of intractable tar." See page 129 in D. R. Augood, G. H. Williams, Chem. Rev. 1957, 57, 123-190.

[11] D. Cantillo, C. Mateos, J. A. Rincon, O. de Frutos, C. O. Kappe, Chem Eur. J. 2015, 21, 12894-12898.

[12] J. R. Beadle, S. H. Korzeniowski, D. E. Rosenberg, B. J. Garcia-Slanga G. W. Gokel J. Org. Chem., 1984, 49, 1594-1603.

[13] For arylation of compounds different from arenes promoted by mild bases, see: a) S. Kindt, K. Wicht, M. R. Heinrich, Org. Lett. 2015, 17 6122-6125; b) W. Erb, A. Hellal, M. Albini, J. Rouden, J. Blanchet Chem. Eur. J. 2014, 20, 6608-6612; c) Z. Xia, Q. Zhu, Org. Lett. 2013 15, 4110-4113; d) D. Koziakov, M. Majek, A. J. von Wangelin, Org. Biomol. Chem. 2016, 14, 11347-11352.

[14] For arylations starting from diazotates, see: a) G. Pratsch, T. Wallaschkowski, M. R. Heinrich, Chem. Eur. J. 2012, 18, 11555-11559; b) S. Kindt, K. Wicht, M. R. Heinrich, Angew. Chem. 2016, 128, 8886 8889; Angew. Chem. Int. Ed. 2016, 55, 8744-8747; c) J. Hofmann, E. Gans, T. Clark, M. R. Heinrich, Chem. Eur. J. 2017, 23, 9647-9656.

[15] a) J. C. Scaiano, L. C. Stewart, J. Am. Chem. Soc. 1983, 105, 3609 3614; b) T. J. Burkey, D. Griller, L. Lunazzi, A. S. Nazran, J. Org. Chem. 
1983, 48, 3704-3707; c) J. Hofmann, T. Clark, Markus R. Heinrich, J. Org. Chem. 2016, 81, 9785-9791.

[16] Oxidation of the lactol $\mathbf{1}$ to the corresponding lactone was unsuccessfully attempted by several methods. See the Supporting Information.

[17] For further information on the control experiments, see the Supporting Information.

[18] J. Gilloteaux, H. L. Lau, I. Gourari, D. Neal, J. M. Jamison, J. L. Summers, Transl. Res. Anat. 2015, 1, 25-39.

[19] G. Silveira-Dorta, D. M. Monzón, F. P. Crisóstomo, T. Martín, V. S. Martín, R. Carrillo, Chem. Commun. 2015, 51, 7027-7030.

[20] O. K. Kwon, J. H. Park, S. K. Park, S. Y. Park, Adv. Energy Mater. 2015, 5, 1400929.

[21] Park and coworkers have synthesized almost the same compound but with a different alkyl chain on the imide. They started from the expensive 2-(5-bromothiophen-2-yl)acetonitrile, which is transformed into the stannate in $47 \%$ yield, and then coupled with the 4 -bromo- $\mathrm{N}-(2-$ ethylhexyl)-1,8-naphthalimide by palladium catalysis in $57 \%$ yield. The global yield is $25 \%$. See reference 21 .

[22] a) H. Tian, S. Wang, Chem. Commun. 2007, 781-792; b) M. Morimoto, M. Irie, Chem. Commun. 2005, 3895-3905.

[23] H. Kamiya, S. Yanagisawa, S. Hiroto, K. Itami, H. Shinokubo, Org. Lett. 2011, 13, 6394-6397.

[24] a) L. Grehn, U. Ragnarsson, Angew. Chem. Int. Ed. 1984, 23, 296-301; b) J. E. Taylor, M. D. Jones, J. M. J. Williams, S. D. Bull, Org. Lett. 2010, 12, 5740-5743.

[25] L. Cui, Z. Peng, C. Ji, J. Huang, D. Huang, J. Ma, S. Zhang, X. Qianb, Y. Xu, Chem. Commun. 2014, 50, 1485-1487.

[26] J. Andersen, U. Madsen, F. Björkling, X. Liang, Synlett, 2005, 22092213.

[27] N. Möller, A. Rühling, S. Lamping, T. Hellwig, C. Fallnich, B. J. Ravoo, F. Glorius, Angew. Chem. Int. Ed., 2017, 56, 4356-4360.

[28] J. Ma, X. Cui, F. Wang, X. Wu, J. Zhao, X. Li, J. Org. Chem., 2014, 79, 10855-10866. 
Entry for the Table of Contents (Please choose one layout)

Layout 1:

\section{FULL PAPER}

Text for Table of Contents

Layout 2:

\section{FULL PAPER}

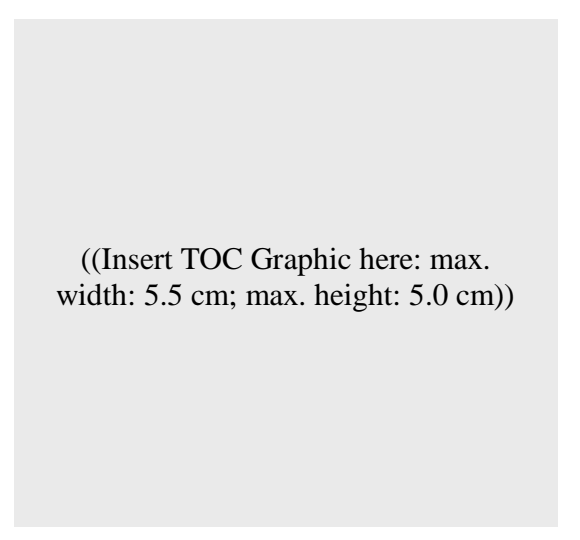

Author(s), Corresponding Author(s)*

Page No. - Page No.

Title
((Insert TOC Graphic here: max. width: $5.5 \mathrm{~cm}$; max. height: $5.0 \mathrm{~cm}$ ))
Diego M. Monzón, Tanausú Santos, F. Pinacho-Crisóstomo, Víctor S. Martín, Romen Carrillo*

Page No. - Page No.

Mild-Base-Promoted Arylation of (Hetero)Arenes with Anilines

Basic Instinct: Mild-base-promoted arylation has been optimized, and applied to the synthesis of molecular cores for material sciences and organic electronics. 